\title{
SEVERAL ISSUES ON SCHOOL ADAPTATION AT PRIMARY LEVEL OF EDUCATION
}

\author{
Tatiana Slezakova - Diana Borbelyova
}

\section{doi: 10.18355/PG.2017.6.2.13}

\begin{abstract}
Start of schooling at a primary level of education is a demanding period changing the life of a child. The child enters the first socially and compulsory role of a schooler out of which a lot of duties arise. These are the same for every child regardless their individual abilities and skills. However, each of them is an individual and deals differently with demanding requirements. The overview study deals with actual problematics of pupil's adaptation to initial education. Recent theoretical approaches as well as results of up-to-day home and foreign research become the main outcomes of this study. They prove the fact that there are lots of adaptation problems and difficulties which may negatively influence not only their schooling career but also physical, mental (psychical) and social health of a child. In the connection with that it is inevitable to pay more attention to this issue not only in a theoretical but also in practical level. Based on experience from abroad the study presents some strategies for solution and these are - creation of conditions in order to provide the continuity of pre-primary and primary education and implementation of adaptation program into initial education which may enable modelling pedagogical and organization conditions in the school environment and thus enable the children to adapt without bigger difficulties.
\end{abstract}

\section{Key words}

school adaptation, primary education, adaptation difficulties, continuity of pre-primary and primary education, adaptation programs

\section{Introduction}

For some children beginning of a systematic education at schools can present a stressful situation as they have to cope with the process of adaptation to micro-social conditions of schools and classrooms. During this period some children suffer from increased sensitivity stemming from these changes. If a child does not feel safe in a new environment, he or she is in a constant tension and cannot find applicable adaptation mechanisms which could diminish the tension in the organism. This can be reflected on educational failures as well as on healthy development of their personalities. As it is proven by many research studies, prolonging the adaptation period; the length and the level of discomfort through which it is experienced by a child influence also the health condition, mainly in the first months of entering the school (see the results of studies presented in Chapter 2).

In Slovakia, as well as in some other foreign countries (e.g. Hungary, Poland, etc.) the issue of adaptation is discussed mainly on the theoretical level. As it is shown by the pedagogical practice, the number of children with delayed school attendance as well as the number of children failing the start of 
education has been growing. Therefore, it is necessary to solve the problems connected with adaptation also on a practical level. According to J. V. Kosenkova (2008) it is necessary to limit the length of this temporary period, limit the criteria for successful adaptation, find applicable methods for identification an individual procedure of this process as well as specifications of learning of each child with the aim to provide them with an adequate support. This study should serve as a holistic picture of the stated problem and based on theoretical and empirical grounds we would like to suggest possible solutions.

The aim of the work is to analyze some of the issues of school adaptation at primary level of education and to present the latest theoretical approaches and the results of existing domestic and international researches in context of child entering school. Another goal is to present some strategies in creating of appropriate conditions to ensure the continuity of pre-primary and primary education, and to focus the attention to the implementation of adaptation programme to the initial instruction, which can be used to model the pedagogical and organizational conditions in the school and then to allow children to adapt without too many difficulties.

\section{Current theoretical background towards solutions of the problems with learner adaptation to initial education}

Problems with adaptation are dealt by many scientific fields such as medicine, physiology, biology, philosophy, psychology as well as sociology and pedagogy. Every scientific field defines and looks into this process from its point of view with the use of professional terminology of that particular discipline. In educational environment we are dealing mainly in the context of the three aspects and that is a physiological, psychological and a social one. Adaptation is from the biological point of view a basic quality of a living organism and covers adjusting morphological and physiological features of the organism to the environmental changes. A social aspect of adaptation presents adjusting of an individual to social conditions, certain rules and norms. The psychological point of view sees the adaptation as a relation of an individual and environment. The change of the environmental conditions for inner misbalance of an organism, which is apparent in a certain character, and the intensity of reactions to certain signals. J. Praska et al. (2003) see a psychological ground of adaptation as the process of human identification with the role or a system of roles which correspond to his or her gender, age, social status, abilities, skills and motives. In some recent studies the psychological and social adaptation is searched as a whole under the term of social and psychological, or psychological and social adaptation (Rjumjanceva, 2012; Slezakova, 2012; Gabiseva, 2013) which applies also to us. In such a view the psychological and social adaptation is understood as a process of active adjustment of an individual to the conditions in social and psychological environment (Slezaková, Tirpakova, 2006).

In terms of a psychological and social adaptation the authors (Soloveva, D.J, 2012; Rumjanceva L.N., 2012; Gennadevna, S.N., 2012) define the school adaptation as a process of an active adjustment of an individual (learner) to 
newly changed conditions of a social environment, and that is a school. It is a process of accepting new social roles and building new social relations.

The role of a schooler becomes the first socially compulsory role to which a child enters. Acceptation and identification with this role is connected with a lot of changes evoking inner unbalance. The start of schooling radically changes stereotypes in the child's behaviour but also the life of the whole family. During this period the child moves from playing into learning activities, the character of his/her relations with the environment changes. The relation towards him/herself reaches another dimension. It is important to realize that the school is not only the place of upbringing and education but at the same time it is an important institution for child's socialization through which they are prepared for the life in the society and get ready for overtaking other life roles. In connection with the socializing function of the school V. Kurincova (2009) defines the following aspects:

- Within school socialisation contributes towards gradual emancipation of a child, his or her initial free from dependence of the parents and the closest family. The child enters various relations among people requiring a high level of their independence and achievement of positive schooling results. They determine also relations of adults towards a child.

- The school is also a place for acquisition of social norms and values. School norms represented in the code of conduct reflect the requirements of a society to behaviour and actions of an individual. By respecting and gradual internalisation of the stated norms the child is being prepared for the life in the society and undertakes other social roles.

- By school results achievement the gradual differentiation of children begins. According to the level of their success reflected by their individual peculiarities, abilities, interests and conditions of family environment, they enter the system of different social relations, perform different roles, activities through which they are prepared for different positions later in their adult lives.

A classroom becomes a significant community in which the aspects of child's socialisation are realized. The way how the child gradually identifies with the role of a schooler depends on the communication style with classmates and a teacher as well as finding a certain position in a classroom and making a relation to learning.

The adaptation of a learner to a new school environment as well as school's adaptation to individual and age particularities of a learner both belongs to the most important conditions. (Kurincova, Slezakova, 2009).

Some children do not have any troubles when they change preschool institutions or family environment for school, however, most of them reflect this process by an increased emotional burden. A new way of life, new people cause the loss of safety and security. Therefore, it is very important for a teacher to create emotionally safe environment which enhances children saturate this need. A key relation is a teacher and a learner, the learner and classmates as well as a process of a gradual acceptation of a learner's role 
playing and an important part also the concordance of the school and family towards the child. As it is mentioned above, the success in accomplishment of school requirements; an ability to start new relationships with a teacher and classmates; non-problematic acquisition of new forms of activities and cooperation at the beginning of school attendance significantly influence the relationship of a pupil to the school, learning and his or her healthy personal development not only at the beginning but also in further years of schooling (Bezrukich, Jefimovova et al., 2000).

In relation with the above mentioned facts the initial education shall provide a gradual and fluent integration of schoolers into a new environment, the effectivity of such a process will depend firstly on the level of school readiness of a child and parents and the last but not least also on the readiness of a teacher and school. A teacher is expected to operate with perfect knowledge of certain adaptation aspects as well as modelling educational conditions developing in the classroom which would help every first-year pupil gradually create adequate mechanisms in order to accept a new position of a schooler. All aspects of the adaptation (physiological, psychological and social) are mutually connected and disrespect of any of those can seriously threaten not only school readiness of a first-year pupil but also his/her health, efficiency, ability to cooperate with a teacher or classmates as well as the competence to respect school rules.

Basic criteria for successful psychological and social adaptation at school are considered as follows: effectivity of learning activities of a child, acquisition of school norms, succeeding in social contacts and emotional comfort (Ceprasova, 2012). Main moments of psychological and social adaptation are considered as follows:

Adaptation to a new daily routine (e.g. new time structure - a lesson, break, compulsory homework, etc.)

- $\quad$ Adaptation to teachers (e.g. new expectations and requirements, new methods of evaluation),

- Adaptation to a classroom (e.g. a new social status, cooperation with classmates),

- Adjustment to new situations and attitudes at home, e.g. new requirements from the side of the parents to a child discipline, other expectations regarding his/her school performance, etc. (Sidorov, Parnjakov, 2012).

A complex view on a process of child's adaptation at the start of school attendance is presented by D. J. Soloveva (2012), (see picture 1), which includes besides basic adaptation criteria also the elements and indicators of success. 


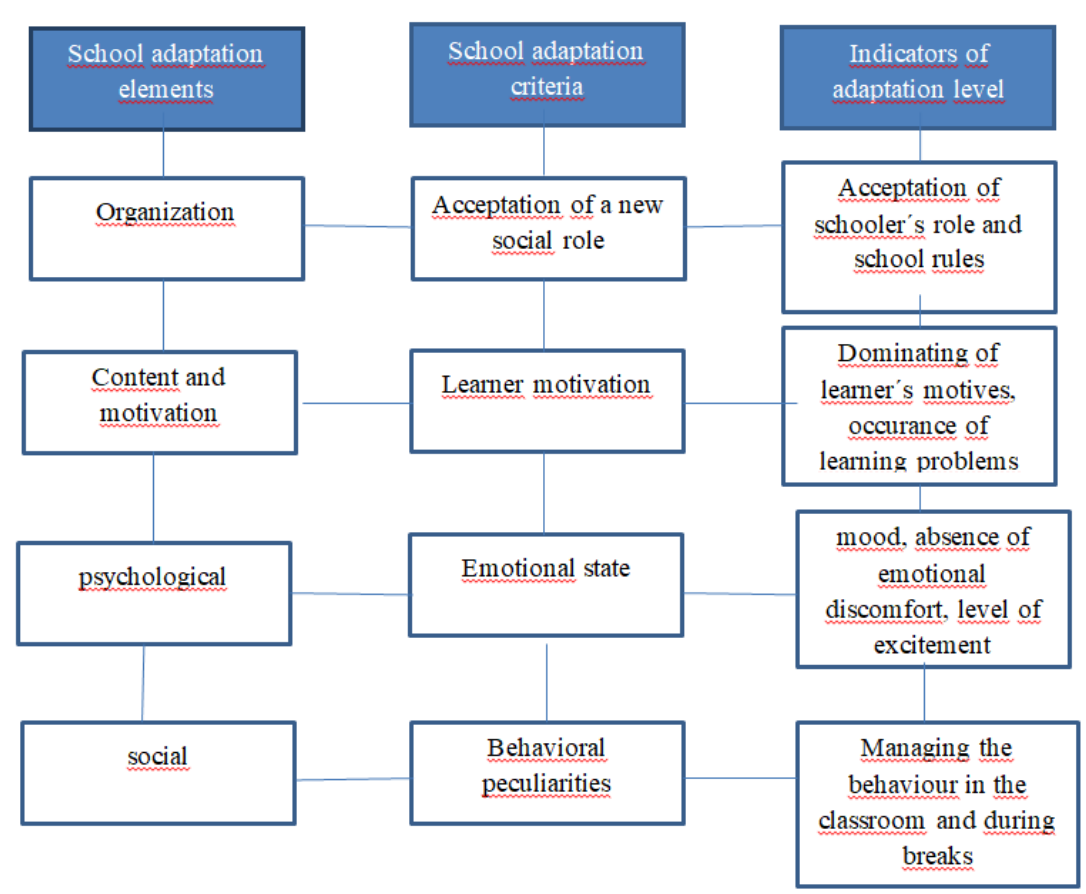

Picture No 1 Structure of school adaptation (In: Solovevova, $2012: 48$ )

The above mentioned structure presents relations among elements, criteria and indicators of school adaptation which enable us objectively search the process and results of a given process.

In order to process the fluent adaptation, it is necessary to respect the following principles:

- Create safe and unthreatening classroom environment (children have to feel safe at school and classroom. They have to feel that the classroom - teachers and classmates - are not threatening).

- Create adequate requirements of a teacher on learner's performance (requirements which are given from the side of adults have to be adequate to his/her abilities and skills).

- Create situations stimulating reaching positive results of a learner in school work (when solving learning tasks a child needs to experience success which helps him/her make positive self-image and trust in their strengths).

"The welcoming school" presumes keeping the above mentioned principles. This school attempts to create optimal conditions for every learner in order to provide achievement of his/her personal maximum (Kasikova, Strakova, 2011).

In general, the professional literature mentions three levels or grades of adaptation which are different from the point of view of the time and quality of changes happening in a child's organisms, his/her survival, behaviour and action (Bezrukich, Jefimovova, 2000; Korotajeva, 2008; Slezakova, Tirpakova, 2006). A teacher can identify them and thus in connection with Slavonic Pedagogical Studies Journal, ISSN 1339-8660, Volume 6 Issue 2, September 2017 
them he/she creates adequate conditions for prevention or elimination of various adaptation difficulties.

An easy adaptation means that children are able to integrate into the classroom within two months; they have no problem with respecting the rules given by a teacher. They are most of the times in a good mood and satisfied. Sometimes these children appear to have minor difficulties in communication with their classmates or a teacher (shouting during the lesson, lack of concentration, tale-telling, showing off, etc.). Until the end of October these limitations shall generally disappear.

A medium level of adaptation means that the period of the child's adaptation to new situations which relating to his/her new status and requirements prolongs. A teacher can see various types of negative behaviour, such as playing during lesson, not responding to teacher's notices. They quite commonly have mood swings accompanied by crying, insults etc. There are also difficulties with the content acquisitions. The period of adaptation takes sometimes half a year.

When adaptation takes more than six months, it is considered to be a severe level. We can see significant problems when maintaining the rules of school life but also at acquisition of school program. These children are unsuccessful at school; they are not popular among classmates or teachers.

In the beginning of the schooling a teacher in cooperation with the parents, psychologist or a special pedagogue has to create optimal conditions for every learner and direct his/her schooling path so that he/she can reach maximum from the potential and was not set apart from successful learners. The most important signal is that a child completely adapts to a new situation is that he/she is satisfied in the classroom, keeps up with the new learning content, a certain level of independence at performance of learning tasks (a child tries to accomplish a task but is also able to ask for help if necessary), an acceptable position in the classroom, among classmates (a child is not popular, has a positive relationship towards other children (Kurincova, Slezakova, 2012). It means that attempts of teachers, parents, psychologist and also special pedagogues should focus on forming the adequate child behaviour, creating contacts with classmates and a teacher as well as making habits from learning activities. Thus, it is possible to eliminate or moderate child's difficulties during the identification with a new role. According to P. Nravdorub (2013) an indicator of successful psychological adaptation is that a child goes to school with happiness, in a good mood, likes doing homework, enjoys talking about school events, has a feeling of being successful and does not turn inwards. If a child performs differently, this proves the fact that he/she has not adapted yet. A lot depends on his/her individual peculiarities, upbringing, cultural and social factors and also interpersonal relations.

The adaptation in the first year of a primary school can be more complicated mainly for the children who have not attended a pre-school institution or they come from disadvantageous families.

These children have not created basic skills to accomplish school requirements, e.g. cooperate with a teacher and classmates, create social contacts, and solve conflicts and other strategies of behaviour and actions. 
Basic tasks of a teacher cover diagnostics of adaptation process and revealing adaptation difficulties, finding their reasons and providing adequate intervention. This activity can be performed by a teacher through the help of different methods. Observation, interview, discussion, sociometria and questionnaires belong to the basic and most frequently used ones. An important part for a teacher is to diagnose a problem in time and thus provide a child with a helping hand. Based on acquired information he/she can determine the problems a child has. Research results show that adaptation problems are estimated properly. These findings comply with the findings of psychologists, studies carried out by special pedagogues and other experts (Kulcsar, 1982).

\section{Reasons of child's adaptation difficulties at the beginning of schooling}

Recent research results realized at home or abroad bring the results proving that for most children the transfer from a pre-school or a family ground to a primary school is problematic.

The difficulties begin right after the start of school during the adaptation period when due to the long-term burden of a child's organism, too much stress (e.g. a child is not able to reach the school's requirements according to expectations of a teacher or parents), insufficient satisfaction of his/her needs (e.g. the need of safety and security), there can be a serious damage of healthy development, the successful identification with the role of a schooler, etc.). Stress negatively influences not only the quality of pupil's social relations but also the quality of his/her learning performances. Unless the adaptation problems and difficulties are eliminated the health problems as for example increased prone illness, frequent headaches and stomach ache, neurosis, etc. Some studies in Hungary prove that 15 to 30 per cent of children have problems with the transfer from the pre-school institution into primary school (Ronkovicsne, Gergely, 2012). V. Kosane Ormai (1989) found out that the adaptation of girls is more successful than boys. Similarly, in the Czech Republic it has been proven that girls in comparison with boys are more adaptable and also more successful at school (Vagnerova, 2000; Janosova, 2008) a d'alší. P. Janosova (2008) claims that in connection with the adaptation difficulties the boys are more frequently diagnosed with school immaturity and learning difficulties. In comparison with the girls it is in the ration of 1:1.6 and 1:6. Her results have expressly shown that the successful process of adaptation does not depend only on possibilities and abilities of a child but also from an expectation of an institution and the way of mediating the expectations. Her further research shows that teachers can strengthen or prevent the adaptation problems. Therefore, the school has to fulfil adaptation, compensation and also resocialisation tasks: help a child to adjust to school conditions, cope with new requirements with the help of proper compensation techniques, and if applicable it has to socially intervene with the aim to integrate pupils with problems into classroom/schooling community.

The studies carried out in Russia focusing on looking into the process of adaptation at the first grade within the first three months have proven that only 32 per cent of children have non-problematic adaptation. 44 per cent fell into the middle level of adaptability. These children have less problems with 
adaptation (an increased need for playing, fear and cry were characteristic for them). They got adapted in the end of the six-month period. A low level of adaptability was characteristic for 20 per cent (problems occurred in feelings, emotional problems, fatigues, exhaustion, a passive protest, strong reactions, agression). Four per cent of children showed maladaptation (with difficulties to meet people, strong reactions, inadequate behaviour, fear, tension, agression, etc.) These children were not able to adapt to the changed conditions even in the second term of the school attendance (Masanskaja, Samsonova, 2013).

Immaturity of certain brain structures and thus insufficiently developed some neuro-psychological functions are claimed to be the most frequent reasons of the problems with adaptation by a lot of experts. In connection with that a child is not capable to overcome the school requirements (Vagnerova, 2001). A. N. Sergejevna (2008), and also other authors claim for the most frequent reasons of school maladaptation the school unreadiness of children, the occurrence of hyperkinetic syndrome and the lack of intellectual competencies.

B. Akcinar (2013) in his first research focused on the significant connection between the level of school adaptation and social and emotional development of an individual.

Besides the internal reasons determining the problems of children in the process of adaptation, some studies bring the facts also about external reasons connected with the school and a teacher. The long-term studies carried out in Russia in the Institute of psychology (Inštitút vozrastnoj psychológie) (Berzrukich, Jefimovova, 2000). The studies realized in Hungary proved that 12 per cent of 3 to 6 -year-old children were sick but this number increased up to 20 per cent at 6 to 8 -year-old children (Nemes, 2001). Similar results found in Germany state that children between 6 and 8 year of age are more often sick than in any other age. Only 14 per cent of children are sick when they are 3 to 6 years of age, it is 24 per cent when children are from 6 to 8-year of age (Vekerdy, 2001).

There are also the studies which prove a significant relation between frequent sickness of some children and a teacher's teaching style. The authoritative and a strict teacher negatively influenced learners 'health (Matjuchina, Michalcik, Prokina, 1984). The use of inadequate methods of a teacher, unacceptance of an individual approach to a child, etc. can be counted among the other reasons of adaptation difficulties (Rumjanceva, 2012).

Some children lose their energy supplies due to the strong pressure on their performance as well as unrespecting the individual tempo of their work. These children can show the signs of aggression, tension, cry, etc. Therefore, it is inevitable for a teacher to respect individual peculiarities of learners, switch activities and employ short movements during the lessons. (Matjuchina, Michalcik, Prokina, 1984).

Other scientific studies speak about a significant influence of the school readiness level on a length of adaptation. T. Slezáková (2011) reached the conclusion that the length of adaptation process for a school is in the significant relation of the reached level in a social and emotional level of the 
learner's development. These results were taken from the research carried out in the academic year 2005/2006 at chosen primary schools in the western part of Slovakia. This research was based on traditional components of school readiness (social and emotional, psychological, physical, work and willing) and its aim was to find out the qualitative changes in the adaptation process of children in a certain period of time as well as the length of the adaptation period. She found out that the children had the biggest problems with the requirements in categories in which social competences were covered (adjustment to the code of conduct, a relation to classmates, an ability of selfrealization in a new environment, and relations of others to a child). Some children were identified with insufficiencies in the field of social motives connected with the learner's role, mainly with an insufficient orientation of a child in this role, and inability to respect the rules. These pupils were not able to create a position in the classroom and were not popular among their classmates. Most of the time they lacked communicative competences (they were not able to engage themselves into activities, they were either worried or quite the opposite, they tended to show off). In all the cases these were the children diagnosed with school immaturity, some of them had not attended a pre-school educational institution, or just the last year before the compulsory school attendance. The author came to the conclusion that insufficiently developed socializing competences make the acceptance of a new pupil's position more difficult.

During his research A. Martin (2013) came to the conclusion that the children with better adaptability were later on more successful in their further lives, they proved to be more flexible to changes, more content and engaged more frequently into the social happenings in comparison with the children with a lower level of adaptability.

Another view on differentiation of reasons for adaptation difficulties and indicators of maladaptation (an inability to adjust to the new conditions) are provided by the more recent scientific studies. When categorizing the reasons coming from the actual changes in educational environment (the content but also the process) determined by the changes and requirements of the society. In our case this is mainly the transfer from learning and a disciplinary model of education into a personally oriented model in which a child is seen as a subject of teaching and the teacher's attention is focused mainly on a learning process of every child.

In this connection a very interesting research by the authors E.V. Leonova, C.S. Satova a E.V. Scerbakova (2014) focusing on finding the relation between the level of personal development competence of a child and his/her successful adaptation to new conditions. The personal competence is defined as an integration of individual and psychological characteristics of child's personality (a child's self-evaluation, intellectual development), a character of a motivational sphere, a level of his/her operational component (an assumption for a learning activity) and communicative competences (an ability of a child to make relations with a teacher and classmates, nonconflict behaviour). By determining the criteria and indicators of an adaptation, they started with particular functions of communication which were divided into the following categories: information and communication 
(a child is able to receive information from a teacher, follow his/her instructions, express interests in new knowledge, is successful at school), regulation and communication (is able to respect school rules, can make contacts with a teacher and classmates, is able to work in a group), and affective and communication (is in a good mood, is satisfied, enjoys going to school, is amiable, or tired, often misses the school, is very introverted).

In the process of finding the reasons for adaptation difficulties the personal competence of a child has been approached as his/her adaptation potential.

Research results proved that a dominating psychological factor conditioning a successful adaptation of a child for school is the level of his/her communication skills - a skill to cooperate with a teacher and classmates. The authors see the reasons of a low level of communication skills of today's children because they have not played enough role plays, much time they spend by watching TV, gaming at the computer, etc. The absence of sufficient "lively" communication in a family as a serious limit and it is apparent (Leonova, Satova, Scerbakova, 2014).

The cooperation among teachers in pre-schools, primary schools and parents is very important in order to prevent or limit the adaptation problems at children. It should be focused on development of personal competences of children coming to the first year of primary schools as well as children who have already become schoolers.

It is evident that the issue of adaptation to school has a lot of dimensions which are possible to be examined in a certain field but there are still new questions inspiring the experts to see it from a different point of view. Coming out of the studies mentioned above we conclude that it is necessary to find a solution which would enable the school adaptation of every child to the highest possible degree as well as eliminate adaptation difficulties. It is important to realize that a thoughtful prevention may prevent the adaptation difficulties. Therefore, we considered important to find the way or strategies by which it is possible to influence the educational reality and improve a situation at our schools. Stemming from the most recent theoretical backgrounds, the results from our and foreign studies and from the practical knowledge we have come to the conclusion that within the primary prevention the possible solutions can be the following:

1. Provision of the continuity between pre-primary and primary education,

2. Realization of an adaptation program in the first year with the help of which it is possible to model the educational environment focusing on the specifications of an adaptation process.

\section{Some strategies preventing adaptation difficulties of children at the beginning of the school attendance \\ Continuity of pre-primary and primary education}

The continuity of pre-primary and primary education has been recently mentioned at different professional and scientific forums. We consider it for very fruitful as there has been also an attempt to create appropriate conditions for a fluent transfer of a child from a preschool institution into the first year of an elementary school. In most of the EU countries there have been 
discussions about connections of the pre-primary and primary education mainly from the reason of making the change from one level to another easier. These countries have also been verifying some models. In total there are three models:

- Integration of ,pre-school” classrooms into the primary education: Netherlands, England

- Attachment of "pre-school" preliminary classrooms to the primary schools: Germany, Belgium, Luxembourg,

- Continuity of educational curricula of the both types of schools educational institutions: France, some countries in Germany.

Every institution focusing on education shall provide a maximum effort in development of child's personality with maintaining its specification. N. P. Sazonova (2010) considers important the following measures within implementation of the fluent transfer of a child from the pre-school period into a young-learner age:

- Primary education shall lean on an achieved level of personal development in a pre-school age,

- Work with a child shall strengthen his/her health, create conditions for individual development of a child and a positive climate,

- The work of both institutions shall be connected in aims, methods as well as the content and forms of educational practice,

- This interconnection shall appear in an upbringing, educational and formative function,

- Interconnection shall be present also in pedagogical requirements and conditions of education of preschoolers and first- year schoolers,

- Mutual cooperation of a school and family within the child's preparation for school and support of non-problematic school adaptation,

- Mutual cooperation of all people involved in the work with children. However, we can state that all the principles are in the practical level accepted in parallel. If an upbringing function and education happen in a playful form, the schooling at a primary level is more oriented to the child's education (the educational function dominates) rather than upbringing. The development of cognitive competences comes forward and the focus is given on learning activities. Not much attention is put on affection and social fields. Primary schools want to produce visible results according to expectation of today's world oriented on achievement. The consequence of a non-complex approach later on causes a large gap between a pre-primary and primary education. Therefore, a child adaptation at a primary level is often problematic.

An important key question of providing the gradual work at a pre-school and primary school appears to be the problem of the child readiness for schooling which becomes, according to many studies (Slezakova, Tirpakova, 2006; Sergejevna, 2008; Janosova, 2008), a primary determinant of the school adaptation. Therefore, it is required to focus mainly on social and emotional readiness of a child. Within the above mentioned measures in favour of easier adaptation we recommend organizing joint programs for children from a pre- 
school and primary schools, visits of pre-schoolers in the classrooms of primary schools; organizing professional forums for teachers of pre-primary and primary education or managing preparation courses or stimulation programs for pre-schoolers at the presence of their parents, joint meetings of teachers and parents of schoolers-to-be, etc.

Implementation of adaptation programs into initial education

An initial idea of our theoretical backgrounds is that undesirable phenomenon and problem occurrence should be prevented by a timely, intentional and well-considered prevention and measures focusing on elimination of stressful situations. In the context of adaptation it is possible to provide a type of security with the help of the program focusing on eliminating or moderating the influence of risk factors and contributes towards maintaining physical, social and psychic health of children. There is no universal and almighty model of solving the adaptation process in the initial education, however, based on the studied methodological materials and the international professional sources we have come to the conclusion that adaptation programs present one model of more possible effective solutions. The aim of our study was to find a solution which prevents adaptation problems with the help of procedures and strategies functioning in the practice. The success of such programs is supported by a long-term tradition with its application in the practice in Russia.

Prevention adaptation programs at the level of school adaptation do not belong to standard services provided at schools in Slovakia. They are not used in the practice and they have not been worked out on the level of state programs. In Russia, more attention is focused on this issue; there are subprograms to the educational programs of schools at more levels of education. At primary level it is e.g. Program for organization of adaptation problems, for maintaining physical, psychic and social health, for elimination of stress and stressful situation or renewing the lost balance of a child when entering the primary school. From our point of view, effectivity lies in optimal periodization of the adaptation process, in considering graduality and cyklicality when increasing the burden of a child stemming from the learning activity as the main activity of a schooler (habits of learning activities of a child are created gradually under the influence of the joint activity with a teacher or classmates). One of the first programs in Russia, which was launched into practice in 1992 was a program called: "Introduction to a schooling life", created by G.A. Cikerman and K.N. Polivanova. The program focused on the first two weeks of education. The following programs belong to the most famous and frequent applied ones:

- I. J. Kusnir - N. M. Mazimuk: "Introducing the school life" - 1995: the program is applied within the first month of schooling education,

- E.V. Vostorgova - S. F. Borbov - Z. N. Novljanskaja - N. L. Tabacnikova- E. V. Cudinova: "New initial education"- 2008. In comparison with the previous programs, this program was elaborated for the whole school year,

- C. I. Gin - I. E. Prokosenko: "First days at school" - 2002, 
- A. B. Voroncov: Modul „First time in the first class“ - 2008: this program is worked out for the first trimester of the schooling (In Voroncov, A. B., 2009).

These programs provide gradual acknowledgment of schoolers with the new environment with the help of games, arts and movements. The main idea is to form a new character of child's relations towards environment, a teacher, classmates and him/herself. In today' pedagogical practice the most commonly used is the "Adaptation program of development learning" by Davydov and El'konin (2008, In Voroncov, 2009). This program starts with the course called "Introduction of child to a school life." It takes approximately three weeks. A teacher works with different games, uses rituals, symbols (introducing the classmates, introduction of „I" symbol, picture of children, classroom's chronicle (what we are like, what we like). An introduction with a new time structure - symbols of a bell, ritual of greeting a teacher, question - answer, the art of listening. A teacher gradually changes individual forms of work with the work in pairs. Children meet the world of the subjects through familiar and close ways and forms of work for them (e.g. Mathematics - building a house: children altogether work on a project of a house, they learn to accept different opinions, decentration noticing a relative notion of their ideas and acquisition of new knowledge at the same time). During a Biology lesson a teacher organizes observation, experiment, and work with questions and involves senses of children. The children thus acquire the way of joint work of the whole class as an individual input. The course finishes with reflections of every child and the whole classroom. The part of it is a display of works called: "My accomplishments".

The problems of adaptation at initial education in our country and abroad has not been solved yet, the foreign models can serve as an inspiration for us so that similar adaptation programs are created and could be applied in our conditions.

\section{Conclusion}

The seriousness of the problems we have been dealing with is documented in different studies and a high number of failing schoolers who fail yet at the beginning of schooling. Therefore, a rather serious problem is a nonsystematic approach towards a solution of an adaptation process and successful start of a child at school. We have come to the conclusion that there is a strong need for a change in traditional understanding of a primary school function. The education at a primary level should not be considered only for traditional content and a disciplinary model but it should come out of the measures of personally oriented pedagogy. The main measure is to respect possibilities and abilities of each child and create "tailor-made" conditions for each of them, respecting specification of every development period and particularly the transitions periods accompanied by a lot of quantitative and qualitative changes in personalities. The start of schooling and a process of adaptation to the changed conditions are very demanding periods in a life of every child and his/her family. Our opinion is that this

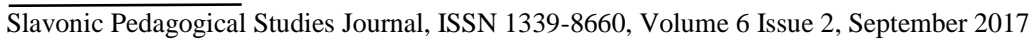


problem deserves much more attention not only in the theoretical but also practical level.

\section{Bibliographics references}

AKCINAR, B. 2013. The Predictors of School Adaptation in Early Childhood. Procedia - Social and Behavioral Sciences. vol. 93, pp. 10991104. [cit. 2013-11-20]. DOI: 10.1016/j.sbspro.2013.09.338. Available online: ttp://www.sciencedirect.com/science/article/pii/S1877042813034411

BEZRUKICH, M. M. - JEFIMOVOVA, S.P. 2000. Rebjonok idjet v skolu. Moskva: Akademia. ISBN 5-7695-0684-9.

CEPRASOVA, S. V. 2014. Adaptacija rebjonka k skole. [cit. 2014-07-14]. Available online: http://nsportal.ru/nachalnajashkola/psikhologiya/adaptatsiya-rebenka-k-skole-1

GABISEVA, A.E. 2000. Socialno-psichologiceskaja adaptacija pervoklassnikov kak uslovije uspesnovo obucenija mladsich skolnikov. [cit. 2014-04-16]. Available online: http://festival.1september.ru/articles/534484/

GENNADEVNA, S. N. 2012. Puti uspesnoj adaptacii pervoklassnikov k skole. [cit. 2014-04-23]. Available online: http://nsportal.ru/nachalnayashkola/dlya-kompleksov-detskii-sad-nachalnaya-shkola/putiuspeshnoy-adaptacii

JANOSOVA, P. 2008. Divci a chlapecka identita. Vyvoj a uskali. Prague: Grada. ISBN 978-80-247-2284-9.

KASIKOVA, H. - STRAKOVA, J. 2011. Diverzita a diferenciace v zakladnim vzdelavani. Praguea: Karolinum. ISBN 978-80-246-1911-8.

KOROTAJEVA, G. S. 2012. Adaptacija k skole. Available online: http://adalin.mospsy.ru/1_04_00/1_04_05.shtml

KOSANE ORMAI, V. 1998. A mi iskoaánk. Nevelespszichologiai modszerek az iskola belso ertekeleseben. Gyor: Szechenyi Nyomda Kft. 245 p. ISBN 9638323248.

KOSENKOVA, J. V. 2008. Adaptacionnyj period rebjonka-pervoklassnika. E-Journal Psychological Science and Edukation. vol.5. ISSN:2074-5885. [cit. 2008-09-02]. Available online: http://psyedu.ru/journal/2008/5/Kosenkova.phtml

KULCSAR, T. 1982. Az iskolai teljesitmeny pszichologiai tenyezoi. Budapest: Tankonyvkiado. ISBN 963-9224-57-X.

KURINCOVA, V. - SLEZAKOVA, T. 2009. Ziak na zaciatku skolskej dochadzky. Edukcna podpora ucitelov a rodicov. Nitra: PF UKF v Nitre. ISBN 978-80-8094-457-5.

LEBEDEVOVA, S. A. 2000. O prejemstvennosti doskolnoho i nacalnoho obrazovanija. Nacalnaja skola, vol.2, no. 1, pp. 20-23.

LEONOVA, E. V. - SATOVA, S. S. - SCERBAKOVA, E. V. 2014. Adaptacija i dezaptacija skolnikov v kontekste trebovanij novych federalnych obrazovatelnych standartov. E-Journal Psychological Science and Edukation. 2014, vol.6, no.4, pp.13-23. ISSN:2074-5885. [cit. 2014-09-02]. Available online: http://www.psyedu.ru

MATJUCHINA, M. V. - MICHALIK, T. S. - PROKINA, N. F. 1984. Vozrastnaja i pedagogiceskaja psychologija. Pedagogiky i metodika nacalnovo obucenija. Moskva: Prosvescenije. 256 p. 
MARTIN, A. 2013. Coping with change: teaching adaptability will help kids grow. University of Sydney. [cit. 2013-11-04]. Available online: http://theconversation.com/coping-with-change-teaching-adaptability-willhelp-kids-grow-9726

MASANSKAJA, A. D. - SAMSONOVA, M.V. 2013. Problema adaptacii rebjonka pervoklassnika $\mathrm{k}$ uslovijam skolnovo obučenija. Metodiceskij material. Krasnojarsk.

NEMES, L. 2001. Pszichogen tünetképződés a kisiskolas korban. Budapest: Akademia Kiado. ISBN 963-05-0119-8.

NRAVDORUB, P. 2013. Psichologiceskaja adaptacija pervoklassnikov $\mathrm{k}$ skole.

[cit.2013-05-24]. Available online: http://www.chudodieta.com/semiya-idom/uyut-igarmoniya/roditeli-i-deti/2675psychologicheskayaadaptactsiyapervoklassnikov -k-skole

PRASKO, J. 2003. Poruchy osobnosti. Prague: Portal. 2003. ISBN: 807178737X.

RONKOVICSNE, FARAGO, E. - GERGELY, K. A. 2012. Az ovoda-iskola atmenet pedagogiaja. Het aranyalma. Budapest: ERFO Nonprofit Kft. ISBN 978-963-89595-0-8.

RUMJANCEVA, L. N. 2012. Psychologo-pedagogiceskoje soprovozdenie adaptacionnovo perioda pervoklassnikov. Učebno-metodiceskoe posobie. Juzno-Sachalinszk: Izdatelstvo Achalinskij Gasudarstvennij Universitet. ISBN 978-5-88811-425-4.

SAZONOVA, N. P. 2010. Doskolnaja pedagogika. Sankt-Peterburg: DetstvoPress. ISBN 978-5-89814-511-8.

SERGEJEVNA, A. N. 2014. Adaptacija pervoklassnikov k skolnym uslovijam. Prilozenie: Komplexnaja programma psichologičeskovo soprovozdenija detej dlja profilaktiki i korekcii skolnoj dezadaptacii. [cit. 2014-04-15]. Available

https://festival.1september.ru/articles/314289/

SIDOROV, P. I. - PARNJAKOV, A.V. 2012. Vvedenie v kliniceskju psichologuju. Adaptacija rebjonka k skole. [online]. [cit. 2014-03-08]. Available online: http://medbookaide.ru/books/fold1002/book2105/p60.php SLEZAKOVA, T. - TIRPAKOVA, A. 2006. Adaptacia dietata na skolu. Nitra: Vydavatelstvo Michala Vaška. 191 p. ISBN 80-8050-968-9.

SLEZAKOVA, T. 2011. Priprava dietata na vstup do skoly ako integralna sucast predprimárnej edukacie. Thesis of habilitation. Presov: Presovska univerzita v Presove. Pedagogicka fakulta.

SLEZAKOVA, T. 2012. Spolocne do skoly. Bratislava: Iris. ISBN 978-8089256-81-5.

SOLOVEVA, D. J. 2012. Faktory adaptacii pervoklassnikov k skole. Voprosi psychologii. Vol. 5, no. 4, pp. 1-9.

VAGNEROVA, M. 2000. Skolni poradenska psychologie pro pedagogy. Prague: Karolinium. ISBN 80-246-1074-4.

VAGNEROVA, M. 2001. Kognitivni a socialni psychologie zaka zakladni skoly. Prague: Karolinum. ISBN 80-246-0181-8.

VEKERDY, T. 2001.Gyerekek, ovodak, iskolak. Budapest: Saxum Kiada Kft. ISBN 9789637168 15X.

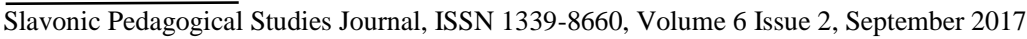


VORONCOV, A. 2014. Systema Ekonina-Davydova. Pedagogicskije uslovija realizacii adaptacionnoho perioda v pervom klasse skol razvivajucseho obucenija. [cit. 2014- 03-08]. Available online: http://nsc.1september.ru/articlef.php?ID=200801308

doc. PaedDr. Tatiana Slezáková PhD.

Department of Education

Faculty of Education

Constantine the Philosopher University

Dražovská 4, 94974 Nitra

Slovakia

tslezakova@ukf.sk

PaedDr. Diana Borbélyová, PhD.

Departement of Preschool and Elementary Education

Faculty of Education

Selye J. University in Komárno

Bratislavská cesta 3322, 94501 Komárno

Slovakia

diana.borbelyova@gmail.com 